\title{
Studies on Effect of Graded Level of Application of Boron and Potassium on Arecanut (Areca catechu L.) and their Interaction on Boron Content in the Soil, Leaf, Nut and Yield Parameter in Terai Region of West Bengal
}

\author{
B.V. Supriya ${ }^{1 *}$, P.S. Medda ${ }^{1}$ and A.K. Sinha ${ }^{2}$ \\ ${ }^{1}$ Department of Plantation, Spices, Medicinal and Aromatic Crops, Faculty of Horticulture, \\ ${ }^{2}$ Department of Soil Science and Agriculture Chemistry, Faculty of Agriculture, Uttar Banga \\ Krishi Vishwavidyalaya, Punibari, West Bengal, India \\ *Corresponding author
}

\begin{abstract}
A B S T R A C T
The experiment was conducted during the year 2017-18 at the instructional farm of Department of Plantation Crops and Processing, Faculty of Horticulture, Uttar Banga Krishi Vishwavidyalaya, West Bengal. The study was aimed to evaluate the effect of graded level application of boron and potassium and their interaction on boron content in soil, leaf and nut $(\mathrm{mg} / \mathrm{kg})$ and their interaction effect on yield parameter in the boron deficient soils of terai region of West Bengal. The experiment was carried out in a $2.7 \times 2.7$ $\mathrm{m}$ spaced 12 year old planted with cv. Mohitnagar and laid out in factorial RBD having 12 treatments replicated 4 times with 4 different level of boron viz., $\mathrm{B}_{0}, \mathrm{~B}_{1}, \mathrm{~B}_{2}$ and $\mathrm{B}_{3}$ at $0 \mathrm{~g}$, $25 \mathrm{~g}, 50 \mathrm{~g}$ and sprayed with $4 \% \mathrm{Na}_{2} \mathrm{~B}_{4} \mathrm{O}_{7}$ solution along with 3 different level of potassium $\left(\mathrm{K}_{2} \mathrm{O}\right)$ viz., $\mathrm{K}_{1}, \mathrm{~K}_{2}$ and $\mathrm{K}_{3}$ at $70 \mathrm{~g}, 140 \mathrm{~g}, 210 \mathrm{~g}$ of $\mathrm{K}_{2} \mathrm{O}$ per palm respectively to the bunches at $2^{\text {nd }}, 4^{\text {th }}$ and $6^{\text {th }}$ months respectively per palm at nut development stage at regular intervals. Soil and nut samples are collected from 10 equidistant spots and 10 different palms respectively whereas leaf sample is collected from the $4^{\text {th }}$ index leaf (Ravi Bhat and Sujatha, 2014) from 10 equidistant palms for analysis before and after application of treatments. The results revealed that graded level application of boron and potassium shows that at higher level of boron $\left(\mathrm{B}_{2}\right)$ and potassium $\left(\mathrm{K}_{3}\right)$ the boron content is gradually increased in the soil, leaf and nut $(\mathrm{mg} / \mathrm{kg})$ and their interaction effect shows that, higher level combination of both boron and potassium $\left(\mathrm{B}_{2} \mathrm{~K}_{3}\right)$ shows higher boron content in the soil, leaf and nut $(\mathrm{mg} / \mathrm{kg})$ and at $\mathrm{B}_{3} \mathrm{~K}_{2}$ and $\mathrm{B}_{2} \mathrm{~K}_{2}$ level of interaction the yield parameters shows significant effect.
\end{abstract}

Keywords

Arecanut

Areca catechu L.

Boron and

Potassium

Article Info

Accepted:

15 February 2019

Available Online:

10 March 2019

\section{Introduction}

The Arecanut is the fruit of the areca palm (Areca catechu) popularly known as betelnut belongs to family arecaceae which grows in much of the Tropical pacific (Melanasia and Micronesia), South East Asia and South Africa. It is mainly chewed with the betel leaves, lime, with or without tobacco. The value added form of consumption is by way of 
pan masala and scented supari. The nut has got some medicinal and neutracritical properties. It is health activator, mouth freshner and has digestive properties. Arecanut can be used for the following purposes like masaj powder, soaps and shampoos, cosmetics, antihelmintic and antidiabetic, areca wine making, areca soft drink, ayurvedic type of thamboola for chewing purpose, ulcer healing combination, hair oil and dyes, food colours and skin ointments (Prakash, 2010). Soil fertility is one of the important factors controlling the crop yield; soil related limitations affecting the crop productivity including nutritional disorders can be determined by evaluating the fertility status of soils. Soil testing provides the information about the nutrient availability of the soil upon which the fertilizer recommendation for maximizing crop yield is made. Boron and Potassium nutrients plays a vital role in the growth and development of arecanut palm where all palms are potassium lovers, required in larger quantity for the development of nuts etc., hence it has to be supplied to the plants in the adequate quantity, both excess supply of minerals and limited supply of nutrients leads to different problems. Due to nutrient deficiency in Terai region soil the plantation under this region are showing greater extent of potassium and boron deficiency which directly effect on nut development which is leading to nut fall, which ultimately reduces the yield of the crop, hence in order to mitigate the problems faced in these regions, it has to be studied scientifically and need to give a solution for all the problems facing related to soil micro and macro nutrients by analyzing the soil, leaf and nut boron and potassium content in interaction with yield parameters.

\section{Materials and Methods}

The experiment was carried out during 201718 at the Instructional Plots of the Department of Plantation Crops and Processing, Uttar Banga Krishi Viswavidyalaya, West Bengal. Physico-chemical properties of the soil analysed by standard methods were soil texture- sandy loam, pH - 5.45 (Jackson, 1973), electrical conductivity - $0.06 \mathrm{dsm}-1$ (Jackson, 1973), available N - 159. $62 \mathrm{~kg} / \mathrm{ha}$ (Alkaline $\mathrm{KMnO}_{4}$ method, Subbiah and Asija, 1956), available P - $23.15 \mathrm{~kg} / \mathrm{ha}$ (Acid extractable method, Bray and Kurtz, 1945), available $\mathrm{K}-145.3 \mathrm{~kg} / \mathrm{ha}$ (1N ammonium acetate method, Jackson, 1967), and available B - $1.77 \mathrm{mg} / \mathrm{kg}$ (Hot water extractable as proposed by Berger and Truog (1939). The experiment was laid out in Factorial Randomised Block Design with 12 treatments replicated 4 times with 4 different level of boron viz $\mathrm{B}_{0}, \mathrm{~B}_{1}, \mathrm{~B}_{2}$ and $\mathrm{B}_{3}$ at $0 \mathrm{~g}, 25 \mathrm{~g}, 50 \mathrm{~g}$ and sprayed with $4 \% \quad \mathrm{Na}_{2} \mathrm{~B}_{4} \mathrm{O}_{7}$ solution along with 3 different level of potassium $\left(\mathrm{K}_{2} \mathrm{O}\right)$ viz $\mathrm{K}_{1}, \mathrm{~K}_{2}$ and $\mathrm{K}_{3}$ at $70 \mathrm{~g}, 140 \mathrm{~g}, 210 \mathrm{~g}$ of $\mathrm{K}_{2} \mathrm{O}$ per palm respectively to the bunches at $2^{\text {nd }}, 4^{\text {th }}$ and $6^{\text {th }}$ months respectively per palm at nut development stage at regular intervals. The 12 different treatment combinations were given in Table 1.

All the palms which are under treatment had given Nitrogen, Phosphorous, potassium and the boron in the form of urea $(46 \%)$, single super phosphate $\left(\begin{array}{lll}16 \% & \mathrm{P}_{2} \mathrm{O}_{5}\end{array}\right)$, muriate of potash $\left(60 \% \quad \mathrm{~K}_{2} \mathrm{O}\right)$ and Borax $(10.5 \% \mathrm{~B})$ respectively. According to the treatment details, the plams were applied with 4 different level of boron viz., $\mathrm{B}_{0}, \mathrm{~B}_{1}, \mathrm{~B}_{2}$ and $\mathrm{B}_{3}$ at $0 \mathrm{~g}, 25 \mathrm{~g}, 50 \mathrm{~g}$ and sprayed with $4 \% \mathrm{Na}_{2} \mathrm{~B}_{4} \mathrm{O}_{7}$ solution along with 3 different level of potassium $\left(\mathrm{K}_{2} \mathrm{O}\right) v i z ., \mathrm{K}_{1}, \mathrm{~K}_{2}$ and $\mathrm{K}_{3}$ at $70 \mathrm{~g}$, $140 \mathrm{~g}, 210 \mathrm{~g}$ of $\mathrm{K}_{2} \mathrm{O}$ per palm respectively to the bunches at $2^{\text {nd }}, 4^{\text {th }}$ and $6^{\text {th }}$ months respectively per palm at nut development stage at regular intervals. A constant dose of Nitrogen was applied in the form of Urea at $109 \mathrm{~g} / \mathrm{palm}$ and phosphorous $\left(\mathrm{P}_{2} \mathrm{O}_{5}\right)$ at $125 \mathrm{~g} / \mathrm{palm}$ in two equal splits at pre and post monsoon. 
Fertilizer are applied in basins around the palm dug to a depth of $15-20 \mathrm{~cm}$ and $0.75-1.0$ $m$ radius from the base of the palm and after the application to the basins were thoroughly mixed with the soil and covered with the top soil. The fertilizer application as stated was followed with light irrigation (Nathanael, 1967 and Dew saliva, 1968). The initial soil samples $0-15 \mathrm{~cm}$ and $15-30 \mathrm{~cm}$ depth were collected randomly throughout the experimental plots before commencement of application of fertilizers mentioned in the experimental details. The soil samples were drawn from the selected from a Dutch Auger (Make: AIC Agro-Industries Private Ltd, Kolkata) as initial sample and later as final sample after the completion of experiment. The sample were collected from base of each palm as separate treatment according to the replication and maintained separately for analysis. In the process, the bulk soil was reduced to $1 \mathrm{~kg}$ by following the quartering method. This $1 \mathrm{~kg}$ soil sample constituted the composite soil sample. The composite soil samples were then air dried, passed through a $2 \mathrm{~mm}$ sieve and stored in clean dry cloth bags with adequate descriptions in attached paper labels. All relevant information and identification marks as required were also recorded. These composite soil samples were analysed in the laboratory for the required soil characteristics and properties and some of the parameters like pH (Jackson, 1973), electrical conductivity (Jackson, 1973), available N (Alkaline $\mathrm{KMnO}_{4}$ method, Subbiah and Asija, 1956), available P (Acid extractable method, Bray and Kurtz, 1945), available (1N ammonium acetate method, Jackson, 1967), and available B (Hot water extractable as proposed by Berger and Truog (1939) has been analysed and also Leaf samples were collected from the $4^{\text {th }}$ index leaf (Bhat and Sujatha, 2014) from 10 equidistant palms for analysis before application of the fertilizer and after completion of the experiment from each palm as per the treatment, 4 samples were collected from each treatment and the bulking of sample and kept separately for analysis and then determination of boron and potassium content in the leaf sample were done.

The collected leaf samples were brought to the laboratory and washed immediately with tap water and then rinsed with $0.1 \mathrm{~N} \mathrm{HCl}$. The washed and rinsed samples were dried under shade followed by oven drying at a temperature of $65 \pm 5^{\circ} \mathrm{C}$ so as to reduce the chemical and biochemical changes to the minimum. The oven dried samples were powdered and stored in butter paper bags for chemical analysis. In the same way nut samples were collected after oven drying the dehusked arecanut, the kernel was dried separately in the oven after separating husk and kernel and then the kernel was grinded, powdered again oven dried and it was kept separately according to the treatment with its replication and proceeded for analysis for both leaf and nut samples of both boron and potassium content has been analysed using Azomethin- $\mathrm{H}$ method and wet digestion method by using tri-acid respectively.

\section{Results and Discussion}

Effect of graded level of application of boron and potassium and their interaction on Boron content in soil, leaf and nut (mg/kg)

\section{Effect of boron and potassium application and their interaction on boron content in the soil (mg/kg)}

Soil analysis data recorded a higher concentration of boron recorded a higher concentration of boron in the soil even at without application of boron $(1.28 \mathrm{mg} / \mathrm{kg})$ and showed directly proportionate relationship to the application of boron. The treatment comprising of without application of boron $\left(\mathrm{B}_{0}\right)$ and bunch spraying $\left(\mathrm{B}_{3}\right)$ recorded 
statistically at par data. As per the analyzed data, it is observed that $\mathrm{B}_{2}(2.52 \mathrm{mg} / \mathrm{kg})$ (Fig. 1) shows significantly higher boron content in the soil and $\mathrm{B}_{0}$ level $(1.28 \mathrm{mg} / \mathrm{kg})$ recorded lower boron content in the soil and also boron content in the soil may also varies based on application of potassium fertilizers at different grades data revealed that treatment $\mathrm{K}_{3}(2.24$ $\mathrm{mg} / \mathrm{kg}$ ) showed significantly higher boron content in the soil and $\mathrm{K}_{1}(1.43 \mathrm{mg} / \mathrm{kg})$ (Table 2; Fig. 1) shows significantly lower boron content.

In the interaction effect of both boron and potassium, the experiment data revealed that $\mathrm{B}_{2} \mathrm{~K}_{3} \quad(3.58 \mathrm{mg} / \mathrm{kg})$ recorded significantly higher boron content in the soil followed by $\mathrm{B}_{2} \mathrm{~K}_{1}(2.13 \mathrm{mg} / \mathrm{kg})$ and $\mathrm{B}_{1} \mathrm{~K}_{3}(2.06 \mathrm{mg} / \mathrm{kg})$ and at the same time $\mathrm{B}_{0} \mathrm{~K}_{1}(0.91 \mathrm{mg} / \mathrm{kg}$ ) (Table 2; Fig. 2) showed significantly lower boron content in the soil. On the other hand bunch spraying of $0.4 \%$ borax recorded an increasing trend of boron concentration of soil with the increasing application of $\mathrm{K}$ in the soil. From the above result it may be concluded that the experimental soils recorded higher boron concentration might be due to regular application of boron into the soil and its concentration increased due to increased rate of soil application of boron.

\section{Effect of boron and potassium application and their interaction on boron content in the leaf (mg/kg)}

The boron content of the index leaf also observed a similar trend as in case of soil $\mathrm{B}_{2}$ level of boron application recorded significantly higher boron content in the leaf (Fig. 1) and $\mathrm{B}_{0}$ showed lowest boron content in the soil (181.82 mg/kg) (Table 2; Fig. 1) where as $\mathrm{K}_{1}$ and $\mathrm{K}_{2}$ level of application recorded significantly lower boron content in the leaf.

Interaction effect of boron and potassium on boron concentration in leaf revealed that $\mathrm{B}_{2} \mathrm{~K}_{3}$
$(225.20 \mathrm{mg} / \mathrm{kg})$ shows significantly higher boron content in the leaf may be due to higher presence of boron in the soil, followed by $\mathrm{B}_{3} \mathrm{~K}_{1}(208.13 \mathrm{mg} / \mathrm{kg}$ ) (Table 2; Fig. 2) and at the same time $\mathrm{B}_{0} \mathrm{~K}_{1}$ recorded significantly lower boron content in the leaf (109.40 $\mathrm{mg} / \mathrm{kg}$ ).

Effect of boron and potassium application and their interaction on boron content in the nut $(\mathrm{mg} / \mathrm{kg})$

Boron concentration in the nut under the treatments is also showed significantly increasing trend as reflected in leaf boron concentration of the palms with the increase in soil application of both the elements and subsequently, $\mathrm{B}_{2}$ and $\mathrm{K}_{2}$ level of application recorded $51.63 \mathrm{mg} / \mathrm{kg}$ and $43.18 \mathrm{mg} / \mathrm{kg}$ respectively. Without application of boron recorded significantly lowest boron content $(24.93 \mathrm{mg} / \mathrm{kg}$ ) followed by bunch spraying of $0.4 \%$ borax (28.40) (Table 2; Fig. 1). The interaction effect of both boron and potassium on boron content in nut reveals the $\mathrm{B}_{2} \mathrm{~K}_{3}$ $(87.06 \mathrm{mg} / \mathrm{kg})$ is having significantly higher boron content in the nut followed by $\mathrm{B}_{1} \mathrm{~K}_{2}$ $\left(48.30 \mathrm{mg} / \mathrm{kg}\right.$ ) and $\mathrm{B}_{2} \mathrm{~K}_{2}(37.77 \mathrm{mg} / \mathrm{kg})$ (Fig. 2) but at the same time $B_{0} K_{1}(19.73 \mathrm{mg} / \mathrm{kg})$ (Table 2; Fig. 1) shows significantly lower boron content in the nut due to lower boron content in the soil as well as leaf.

Interaction effect of boron and potassium application on fresh kernel weight (g) and Dry kernel weight (g)

\section{Interaction effect of boron and potassium application on fresh kernel weight (g)}

The results with respect to the effect of boron and potassium at different levels indicated that $\mathrm{B}_{3} \mathrm{~K}_{2}$ (13.03 g) (Fig. 3) produced significantly higher kernel weight and was at par with remaining all 10 treatments but $\mathrm{B}_{2} \mathrm{~K}_{1}(10.18 \mathrm{~g})$ (Fig. 3) produced significantly lower kernel weight. 
Table.1 Treatment details

\begin{tabular}{|c|c|}
\hline $\mathbf{T}_{1}: \mathbf{B}_{0} \mathbf{K}_{1}$ & $0 \mathrm{~g}$ borax/palm $(0 \mathrm{~g} \mathrm{~B})+70 \mathrm{~g} \mathrm{~K}$ (O/palm \\
\hline $\mathbf{T}_{2}: \mathbf{B}_{0} \mathbf{K}_{2}$ & $0 \mathrm{~g}$ borax/palm $(0 \mathrm{~g} \mathrm{~B})+140 \mathrm{~g} \mathrm{~K}_{2} \mathrm{O} /$ palm \\
\hline $\mathbf{T}_{\mathbf{3}}: \mathbf{B}_{\mathbf{0}} \mathbf{K}_{\mathbf{3}}$ & $0 \mathrm{~g}$ borax/palm $(0 \mathrm{~g} \mathrm{~B})+210 \mathrm{~g} \mathrm{~K}_{2} \mathrm{O} /$ palm \\
\hline $\mathbf{T}_{4}: \mathbf{B}_{1} \mathbf{K}_{1}$ & $25 \mathrm{~g}$ borax/palm $(2.63 \mathrm{~g} \mathrm{~B})+70 \mathrm{~g} \mathrm{~K}_{2} \mathrm{O} /$ palm \\
\hline $\mathbf{T}_{5}: \mathbf{B}_{1} \mathbf{K}_{2}$ & $25 \mathrm{~g}$ borax/palm $(2.63 \mathrm{~g} \mathrm{~B})+140 \mathrm{~g} \mathrm{~K}_{2} \mathrm{O} /$ palm \\
\hline $\mathbf{T}_{6}: \mathbf{B}_{1} \mathbf{K}_{3}$ & $25 \mathrm{~g}$ borax$/$ palm $(2.63 \mathrm{~g} \mathrm{~B})+210 \mathrm{~g} \mathrm{~K}_{2} \mathrm{O} /$ palm \\
\hline $\mathbf{T}_{7}: \mathbf{B}_{2} \mathbf{K}_{1}$ & $50 \mathrm{~g}$ borax/palm $(5.25 \mathrm{~g} \mathrm{~B})+70 \mathrm{~g} \mathrm{~K}_{2} \mathrm{O} /$ palm \\
\hline $\mathbf{T}_{8}: \mathbf{B}_{2} \mathbf{K}_{2}$ & $50 \mathrm{~g}$ borax/palm $(5.25 \mathrm{~g} \mathrm{~B})+140 \mathrm{~g} \mathrm{~K}_{2} \mathrm{O} / \mathrm{palm}$ \\
\hline $\mathbf{T}_{\mathbf{9}}: \mathbf{B}_{\mathbf{2}} \mathbf{K}_{\mathbf{3}}$ & $50 \mathrm{~g}$ borax/palm $(5.25 \mathrm{~g} \mathrm{~B})+210 \mathrm{~g} \mathrm{~K}_{2} \mathrm{O} /$ palm \\
\hline $\mathbf{T}_{10}: \mathbf{B}_{3} \mathbf{K}_{1}$ & Spray $0.4 \% \mathrm{Na}_{2} \mathrm{~B}_{4} \mathrm{O}_{7}+70 \mathrm{~g} \mathrm{~K}_{2} \mathrm{O} /$ palm \\
\hline $\mathbf{T}_{11}: \mathbf{B}_{3} \mathbf{K}_{2}$ & Spray $0.4 \% \mathrm{Na}_{2} \mathrm{~B}_{4} \mathrm{O}_{7}+140 \mathrm{~g} \mathrm{~K}_{2} \mathrm{O} /$ palm \\
\hline $\mathbf{T}_{12}: \mathbf{B}_{3} \mathbf{K}_{3}$ & Spray $0.4 \% \mathrm{Na}_{2} \mathrm{~B}_{4} \mathrm{O}_{7}+210 \mathrm{~g} \mathrm{~K}_{2} \mathrm{O} /$ palm \\
\hline
\end{tabular}

Table.2 Effect of graded level of application of boron and potassium and their interaction on Boron content in soil, leaf and nut $(\mathrm{mg} / \mathrm{kg})$

\begin{tabular}{|c|c|c|c|}
\hline Treatment & $\begin{array}{l}\text { Boron content in the soil } \\
(\mathrm{mg} / \mathrm{kg})\end{array}$ & $\begin{array}{l}\text { Boron content in the } \\
\text { leaf }(\mathrm{mg} / \mathrm{kg})\end{array}$ & $\begin{array}{c}\text { Boron content in the } \\
\text { nut }(\mathrm{mg} / \mathrm{kg})\end{array}$ \\
\hline $\mathbf{B}_{0}$ & 1.28 & 147.84 & 24.93 \\
\hline $\mathbf{B}_{1}$ & 1.76 & 174.52 & 34.79 \\
\hline $\mathbf{B}_{2}$ & 2.52 & 200.54 & 51.63 \\
\hline $\mathbf{B}_{3}$ & 1.45 & 170.53 & 28.40 \\
\hline $\operatorname{S.Em}( \pm)$ & 0.08 & 1.52 & 0.72 \\
\hline C.D. (0.05) & 0.23 & 4.45 & 2.12 \\
\hline $\mathbf{K}_{1}$ & 1.43 & 168.86 & 27.27 \\
\hline $\mathbf{K}_{2}$ & 1.58 & 169.41 & 34.43 \\
\hline $\mathbf{K}_{3}$ & 2.24 & 181.82 & 43.18 \\
\hline $\operatorname{S.Em}( \pm)$ & 0.07 & 1.31 & 0.63 \\
\hline C.D(0.05) & 0.19 & 3.86 & 1.83 \\
\hline $\mathbf{B}_{0} \mathbf{K}_{1}$ & 0.91 & 109.40 & 19.73 \\
\hline $\mathbf{B}_{0} K_{2}$ & 1.45 & 113.00 & 26.77 \\
\hline $\mathbf{B}_{\mathbf{0}} \mathbf{K}_{3}$ & 1.49 & 121.13 & 28.30 \\
\hline $\mathbf{B}_{1} \mathbf{K}_{1}$ & 1.45 & 153.13 & 27.30 \\
\hline $\mathbf{B}_{1} \mathbf{K}_{2}$ & 1.77 & 180.47 & 48.30 \\
\hline $\mathbf{B}_{1} \mathbf{K}_{3}$ & 2.06 & 189.97 & 28.77 \\
\hline $\mathbf{B}_{2} \mathbf{K}_{1}$ & 2.13 & 204.77 & 30.07 \\
\hline $\mathbf{B}_{2} \mathbf{K}_{2}$ & 1.85 & 171.67 & 37.77 \\
\hline $\mathbf{B}_{2} \mathbf{K}_{3}$ & 3.58 & 225.20 & 87.06 \\
\hline $\mathbf{B}_{3} \mathbf{K}_{1}$ & 1.24 & 208.13 & 24.97 \\
\hline $\mathbf{B}_{3} \mathbf{K}_{2}$ & 1.27 & 190.97 & 31.93 \\
\hline $\mathbf{B}_{\mathbf{3}} \mathbf{K}_{\mathbf{3}}$ & 1.85 & 112.50 & 28.30 \\
\hline $\operatorname{S.Em}( \pm)$ & 0.13 & 2.63 & 1.25 \\
\hline C.D(0.05) & 0.39 & 7.71 & 3.67 \\
\hline
\end{tabular}


Table.3 Interaction effect of boron and potassium application on fresh kernel weight $(\mathrm{g})$ and dry kernel weight

\begin{tabular}{|c|c|c|}
\hline Treatment & Fresh kernel weight (g) & Dry kernel weight (g) \\
\hline $\mathbf{B}_{\mathbf{0}} \mathbf{K}_{\mathbf{1}}$ & 11.34 & 3.00 \\
\hline $\mathbf{B}_{\mathbf{0}} \mathbf{K}_{\mathbf{2}}$ & 12.32 & 3.61 \\
\hline $\mathbf{B}_{\mathbf{0}} \mathbf{K}_{\mathbf{3}}$ & 12.64 & 3.01 \\
\hline $\mathbf{B}_{\mathbf{1}} \mathbf{K}_{\mathbf{1}}$ & 12.41 & 3.26 \\
\hline $\mathbf{B}_{\mathbf{1}} \mathbf{K}_{\mathbf{2}}$ & 12.74 & 3.01 \\
\hline $\mathbf{B}_{\mathbf{1}} \mathbf{K}_{\mathbf{3}}$ & 12.33 & 3.09 \\
\hline $\mathbf{B}_{\mathbf{2}} \mathbf{K}_{\mathbf{1}}$ & 10.18 & 3.01 \\
\hline $\mathbf{B}_{\mathbf{2}} \mathbf{K}_{\mathbf{2}}$ & 12.94 & 3.88 \\
\hline $\mathbf{B}_{\mathbf{2}} \mathbf{K}_{\mathbf{3}}$ & 11.84 & 3.11 \\
\hline $\mathbf{B}_{\mathbf{3}} \mathbf{K}_{\mathbf{1}}$ & 10.82 & 3.00 \\
\hline $\mathbf{B}_{\mathbf{3}} \mathbf{K}_{\mathbf{2}}$ & 13.03 & 3.73 \\
\hline $\mathbf{B}_{\mathbf{3}} \mathbf{K}_{\mathbf{3}}$ & 12.53 & 3.44 \\
\hline $\mathbf{S . E m} \mathbf{(} \mathbf{(})$ & $\mathbf{0 . 6 4}$ & $\mathbf{0 . 2 9}$ \\
\hline C.D. $(\mathbf{0 . 0 5})$ & $\mathbf{1 . 8 8}$ & $\mathbf{0 . 8 5}$ \\
\hline
\end{tabular}

Fig.1 Effect of graded level of application of boron and potassium on boron content in soil, leaf and nut $(\mathrm{mg} / \mathrm{kg})$

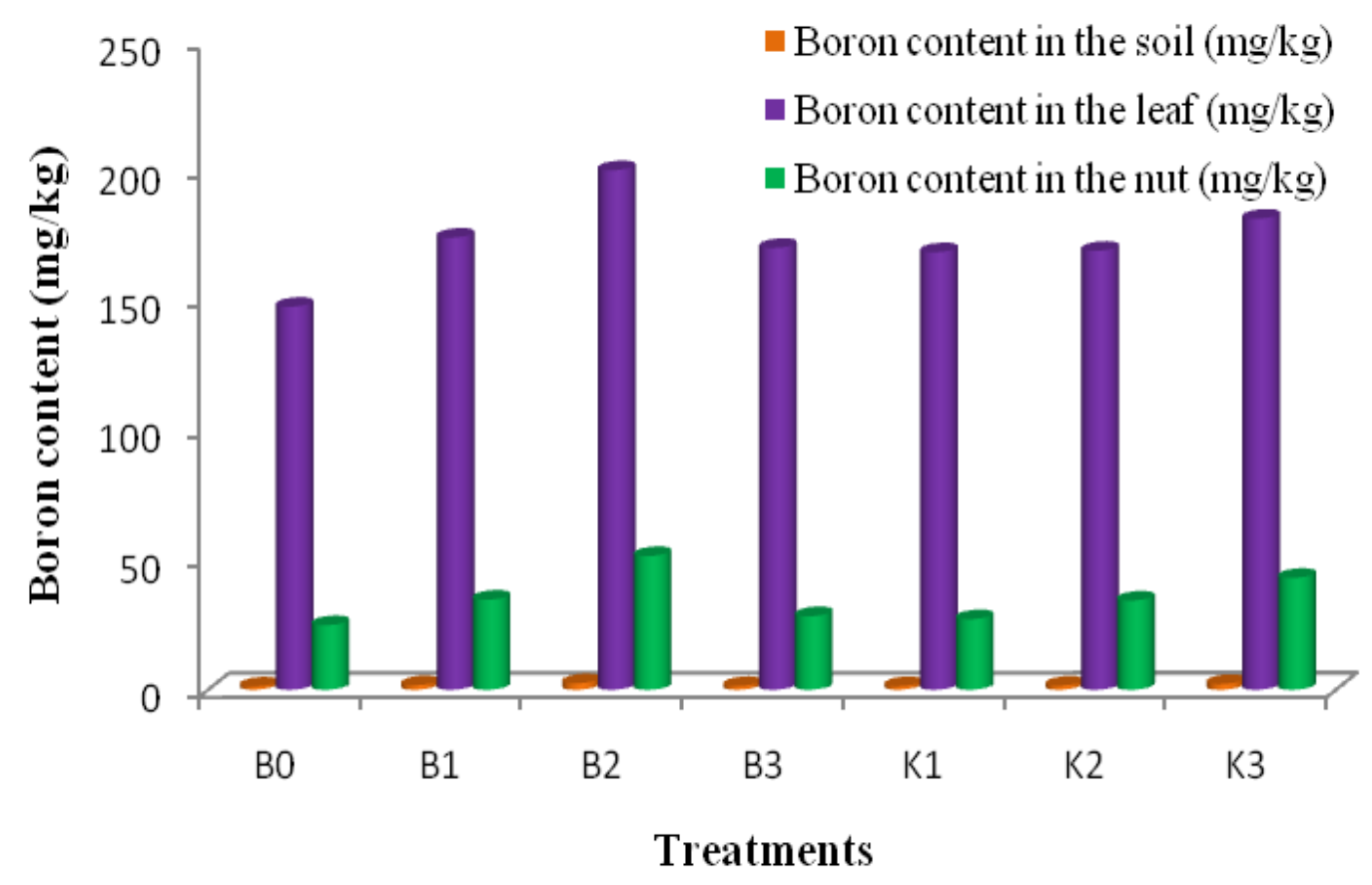


Fig.2 Interaction effect of graded level of application of boron and potassium on boron content in soil, leaf and nut $(\mathrm{mg} / \mathrm{kg})$

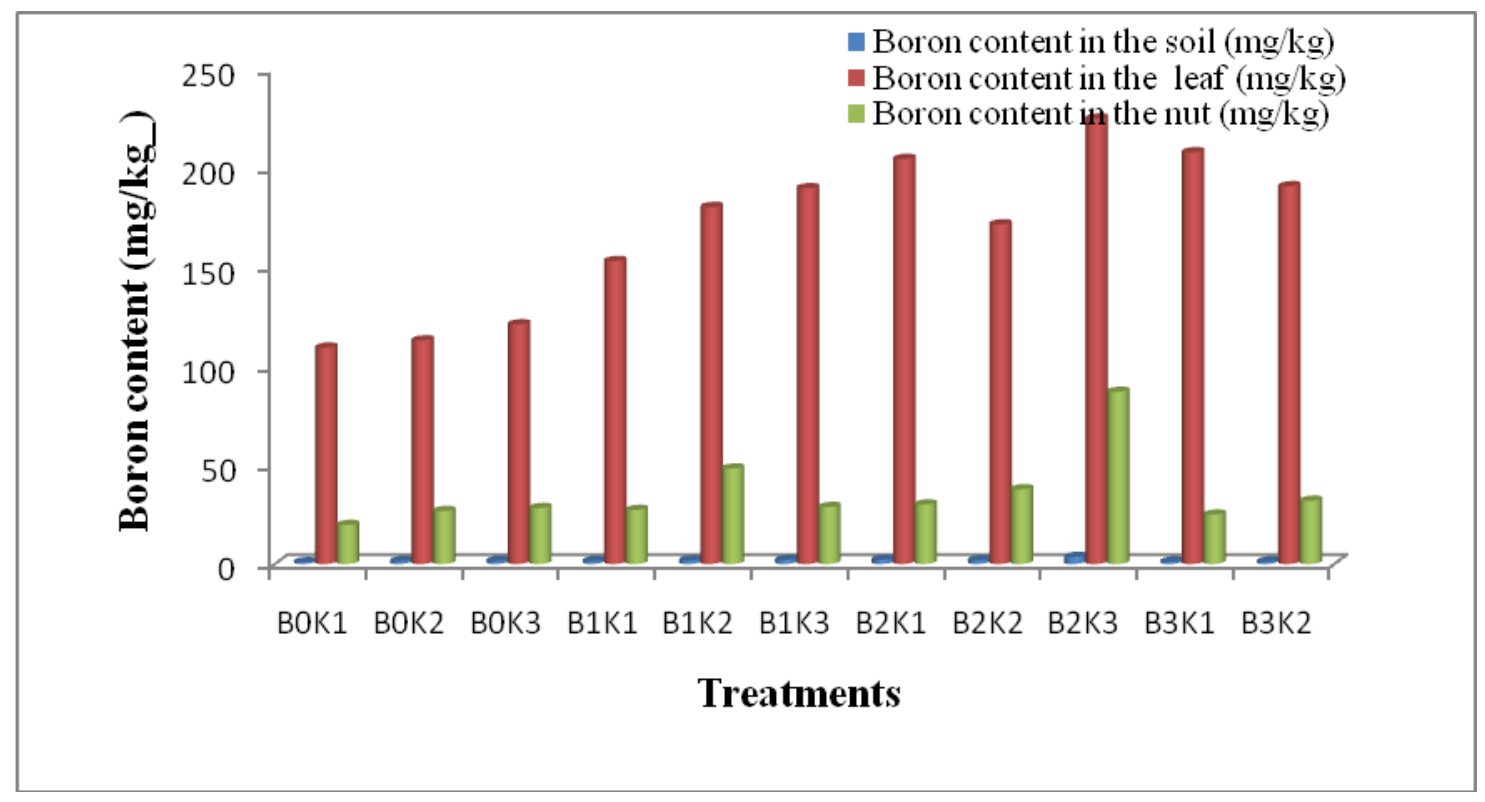

Fig.3 Interaction effect of boron and potassium application on fresh kernel weight (g) and dry kernel weight

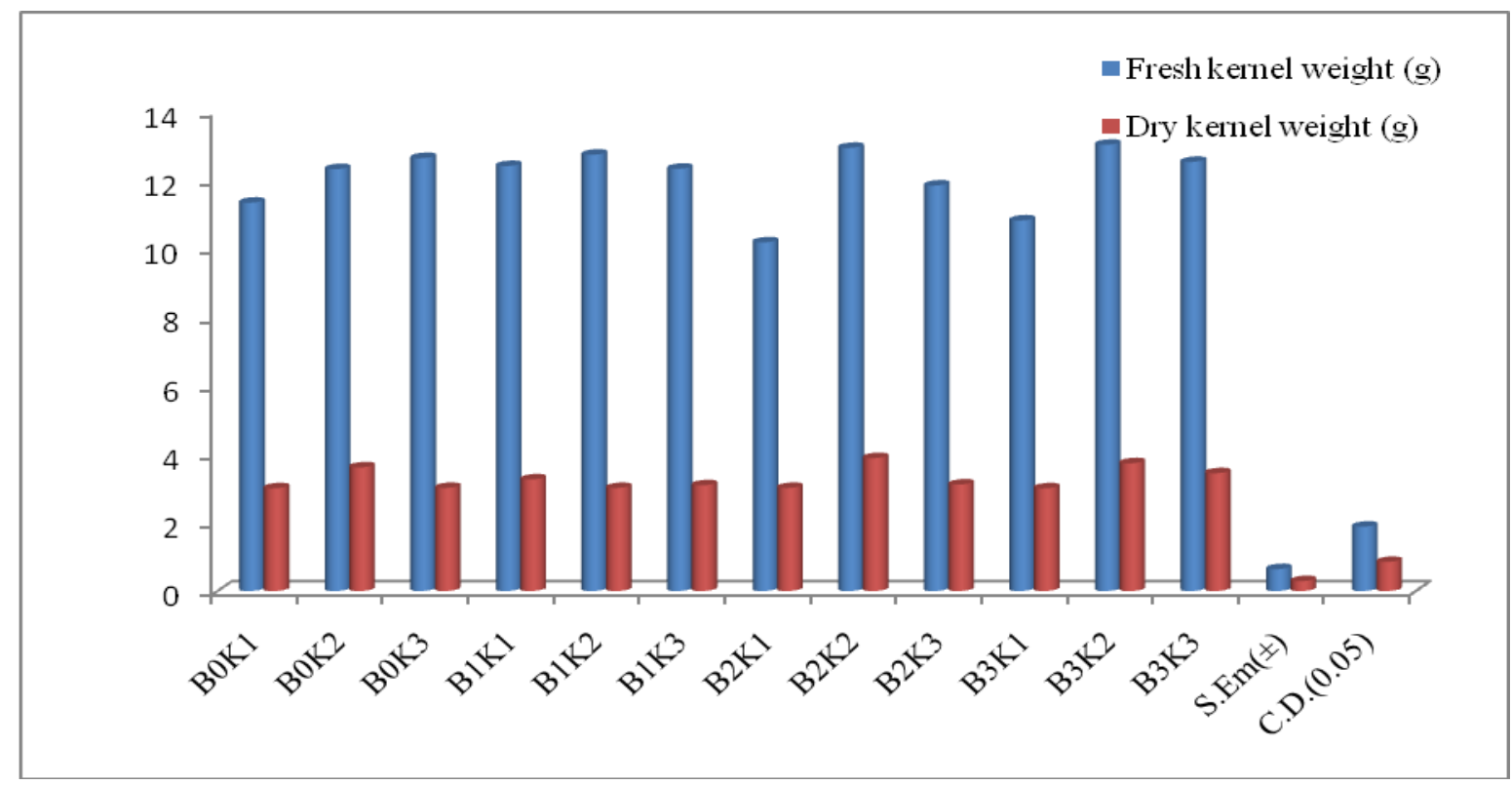

The data suggested that bunch spray with higher dose of potassium had a significant effect at lower boron concentration in soil and helped potassium play a role in physiological activity.
Interaction effect of boron and potassium application on dry kernel weight (g)

Interaction effect of both minerals, the experimental data reveals that $\mathrm{B}_{2} \mathrm{~K}_{2}(3.80 \mathrm{~g})$ level shows significantly higher dry kernel 
weight followed by $\mathrm{B}_{3} \mathrm{~K}_{2}(3.73 \mathrm{~g})$ and $\mathrm{B}_{0} \mathrm{~K}_{2}$ (3.61 g) (Table 3; Fig. 3) as noticed with respect to fresh kernel weight, may be due to better combination of both nutrients and $\mathrm{B}_{0} \mathrm{~K}_{1}$ level of application recorded significantly lower dry kernel weight(3.00 g) due to lower availability and ultimately reflected in dry matter accumulation.

From the experiment we can conclude that the graded levels of boron and potassium and their interaction indicated that there was a significant increase in boron level of soil, leaf and nut with increase level of soil application of boron and potassium. The interaction of both the elements was also showed the similar effect with respect to boron concentration

In the present experiment, yield attributing characters of the arecanut have also observed varied response with application of different combination of boron and potassium. Soil application of $25 \mathrm{~g}$ boron and $140 \mathrm{~g}$ potassium per palm recorded the maximum fresh kernel weight of the nuts and dry kernel weight recorded its maximum value with bunch spray along with soil application of 140 $\mathrm{g}$ potassium. However, the treatment combination $\mathrm{B}_{3} \mathrm{~K}_{2}$ performed the best with respect to fresh kernel weight and $\mathrm{B}_{2} \mathrm{~K}_{2}$ performed the best with respect to dry kernel.

Better yield of arecanut cv Mohitnagar can be achieved through combined soil application of $25 \mathrm{~g}$ borax with $140 \mathrm{~g}$ potash along with 100 $\mathrm{g}$ nitrogen and $40 \mathrm{~g}$ phosphorous. Regular soil application of boron increases the boron concentration of soil, leaf and nut which hinders the increased uptake of potassium.

\section{References}

Berger, K.C. and Truog, E. (1939). Boron determination in soils and plants. Industrial Engineering Chemistry, 11: $540-545$.

Bhat and Sujatha, S. (2014). Nutrient management in arecanut. Indian Journal of Arecanut, Spices and Medicinal plants, 16(4).

Bray, R.H. and Kurtz, L.P. (1945). Determination of total, organic and available forms of phosphorus in soils. Soil Science, 59: 39-45.

Jackson, M.L. (1967). Soil Chemical Analysis. Prentice Hall of India Private Limited, New Delhi.

Jackson, M.L. (1973). Soil chemical analysis, Prentice Hall of India, Pvt. Ltd., New Delhi.

Nathanael, W.R.N. (1967). The application of fertilizer to adult coconut palms in relation to theoretical aspects. Ceylon Coconut Quarterly, 18:1- 30.

Prakash, T.N. (2010). Special scheme on cost of cultivation of arecanut from Karnataka, Department of Agricultural Economics, University of Agricultural Sciences, Bangalore.

Subbiah, B.V. and Asija, G.L. (1956). A rapid procedure for determination of available nitrogen in soils. Cur. Sci., 25: 259-260.

\section{How to cite this article:}

Supriya, B.V., P.S. Medda and Sinha, A.K. 2019. Studies on Effect of Graded Level of Application of Boron and Potassium on Arecanut (Areca catechu L.) and their Interaction on Boron Content in the Soil, Leaf, Nut and Yield Parameter in Terai Region of West Bengal. Int.J.Curr.Microbiol.App.Sci. 8(03): 1992-1999. doi: https://doi.org/10.20546/ijcmas.2019.803.237 